\title{
High bioaccumulation of cadmium and other metals in Patagonian edible gastropods
}

\section{Mónica A. Primost, Mónica N. Gil \& Gregorio Bigatti}

To cite this article: Mónica A. Primost, Mónica N. Gil \& Gregorio Bigatti (2017): High bioaccumulation of cadmium and other metals in Patagonian edible gastropods, Marine Biology Research, DOI: 10.1080/17451000.2017.1296163

To link to this article: http://dx.doi.org/10.1080/17451000.2017.1296163

$$
\text { 曲 Published online: } 08 \text { Jun } 2017 .
$$

Submit your article to this journal $₫$

Q View related articles $ک$

View Crossmark data 


\title{
High bioaccumulation of cadmium and other metals in Patagonian edible gastropods
}

\author{
Mónica A. Primost ${ }^{a}$, Mónica N. Gil ${ }^{b, c}$ and Gregorio Bigatti ${ }^{a, c}$ \\ a'LARBIM - IBIOMAR (CCT CONICET CENPAT), Puerto Madryn, Chubut. Argentina; ${ }^{b}$ LAQUIAE (CCT CONICET CENPAT), LOQYCA-CESIMAR (CCT \\ CENPAT), Puerto Madryn, Chubut. Argentina; ${ }^{C}$ Facultad de Ciencias Naturales, Universidad Nacional de la Patagonia San Juan Bosco \\ (UNPSJB), Puerto Madryn, Chubut. Argentina
}

\begin{abstract}
High concentrations of metals are accumulated by edible marine resources, affecting human health. Marine gastropods have been commercially captured and consumed in Argentina for decades without official regulations or studies to guarantee their safety. In this study, metals (cadmium, aluminium, iron, zinc, copper and lead) were analysed for the first time in the edible marine gastropods Buccinanops globulosus, Adelomelon ancilla and Trophon geversianus and their surrounding sediments. Taking into account the maximum levels recommended by national and international regulations for food safety, we recommend consuming only the foot of these gastropod species. We recommend not consuming these gastropods from harbour areas due to concentrations of lead in sediments and tissues. Though the target hazard quotient (THQ) of cadmium was not high for the local community, it could be higher for other populations who consume molluscs more frequently, indicating a potential health risk of chronic exposure. Monitoring of these and other contaminants should be performed in order to ensure food safety of these marine resources.
\end{abstract}

ARTICLE HISTORY

Received 4 November 2016

Accepted 9 February 2017

\section{RESPONSIBLE EDITOR}

Sharon Hook

\section{KEYWORDS}

Cadmium; human risk; marine pollution;

Neogastropoda; Patagonia

\section{Introduction}

Trace elements naturally occur in the sea, while environmental levels may be increased by natural processes as well as anthropogenic activities. Marine organisms incorporate metals from their surroundings, depending on abiotic factors as well as on the characteristics of the species, the exposure period and the concentration and chemical speciation of the elements (Langston et al. 1998). As a result, biota can accumulate metals in high concentrations and human health can be at risk because of consumption of contaminated seafood.

Marine molluscs, in particular gastropods, have widely been used as bioindicators, since several negative effects are evident as a consequence of exposure to endocrine disrupters in polluted environments (Meador et al. 1995). Metals have been reported in tissues of marine gastropods such as Nucella lapillus (Linnaeus, 1758), Reisha clavigera (Küster, 1860), Tritia reticulata (Linnaeus, 1758) and other species (Bryan et al. 1987; Blackmore \& Morton 2002; Wang \& Ke 2002; Gust et al. 2011). In general, the digestive gland has been the target of study due to its involvement in metabolic processes and its role in detoxification
(Regoli \& Orlando 1994; Marigomez et al. 2002; Wang $\&$ Ke 2002). Since most marine gastropods are edible, many authors have also assessed their potential risk to human consumption due to their ability to accumulate toxic metals (Conti et al. 2012a; Copat et al. 2013; Bat et al. 2016; Lahbib et al. 2016).

On the marine coast of Patagonia Argentina, there have been many studies of metal accumulation in abiotic and biotic components (Gil et al. 2006; Conti et al. 2011; Giarratano et al. 2013). However, metal content in marine gastropods has only been reported for the limpet Nacella magellanica (Gmelin, 1791) in the Beagle Channel, at the southernmost tip of Argentina (Conti et al. 2012b).

This study was conducted on the west coast of Nuevo Gulf, in Northern Atlantic Patagonia. The most important economic activities in the region are fisheries, aluminium production and tourism based on local fauna such as the whale Eubalaena australis (Desmoulins, 1822). An important maritime activity has also been developed within Nuevo Gulf. Various species of edible gastropods belonging to Nassariidae, Muricidae and Volutidae inhabit this coastal zone. We studied three species: Adelomelon ancilla (Lightfoot, 1786),

CONTACT M. A. Primost primost@cenpat-conicet.gob.ar $@$ LARBIM - IBIOMAR (CONICET), Bvd. Brown 2915 (U9120ACV), Puerto Madryn, Chubut. Argentina

2017 Informa UK Limited, trading as Taylor \& Francis Group 
which feeds on live bivalves and other gastropod species, and inhabits mixed sediments (Zabala et al. 2013a); Buccinanops globulosus (Kiener, 1832) (=Buccinanops deformis (King, 1832) sensu Scarabino et al. 2006), which feeds on carrion (Bökenhans 2014) and lives buried in muddy sediments (Scarabino 1977); and Trophon geversianus (Pallas, 1774), which inhabits the bivalve complex Brachidontes rodriguezii (d'Orbigny, 1842)/Perumytilus purpuratus (Lamarck, 1819) and feeds on them. These gastropods are locally consumed and commercialized albeit without official regulations or safety quality controls (Narvarte 2006; Bigatti \& Ciocco 2008; Bigatti et al. 2015). Between 2000 and 2004, the annual catch of B. globulosus in San Matías Gulf was up to 9 tons with an estimated price per kilogram in 2015 of US\$7.7.

Metals such as zinc and copper are nutritional elements, although they can be toxic in high concentrations. Iron is widely recognized as essential to marine organisms (Butler 1998) and aluminium has no known biological function (Exley \& Mold 2015). Lead and cadmium are considered to be toxic even at low concentrations (WHO 2006). In this paper, we determined for the first time the metal contents (cadmium (Cd), aluminium (Al), iron (Fe), Zinc ( $\mathrm{Zn})$, copper $(\mathrm{Cu})$ and lead $(\mathrm{Pb}))$ in the edible gastropods B. globulosus, A. ancilla and T. geversianus and explored their potential risk for human health through dietary intake. The main substrate where each species lives and feeds (sediments and small mussels, B. rodriguezii/P. purpuratus) was also analysed.
Sediment toxicity to biota was assessed by comparison of measured concentrations with national and international guidelines.

\section{Material and methods}

\section{Study area and sampling}

Samples were collected in Nuevo Gulf, at four sites with different levels of anthropogenic activity: Storni harbour (SH), Luis Piedra Buena harbour (LPBH) and the beaches of Punta Cuevas (PC) and Cerro Avanzado (CA) (Figure 1). The level of anthropogenic activity at these sites has been assessed previously. There are two harbours characterized by the presence of commercial, fishing and recreational vessels ( $\sim 700$ vessels per year) (APPM 2016). Moderate levels of trace metals, polycyclic aromatic hydrocarbons (PAHs) and tributyltin (TBT) were previously recorded in sediments and bivalve molluscs (Gil et al. 1999; Massara Paletto et al. 2008; Bigatti et al. 2009). The PC site is a recreational area; low trace metals and TBT pollution were reported in sediments and marine organisms (Bigatti et al. 2009; Di Salvatore et al. 2013; Giarratano et al. 2013). In contrast, CA is a site with scarce vessel traffic and where diving activities are occasionally performed. It has been considered as a control site in pollution studies related to hydrocarbons, tributyltin and booster biocides (Bigatti et al. 2009; Del Brio et al. 2016). Three gastropod species were collected in a unique sampling event. Approximately 30 specimens

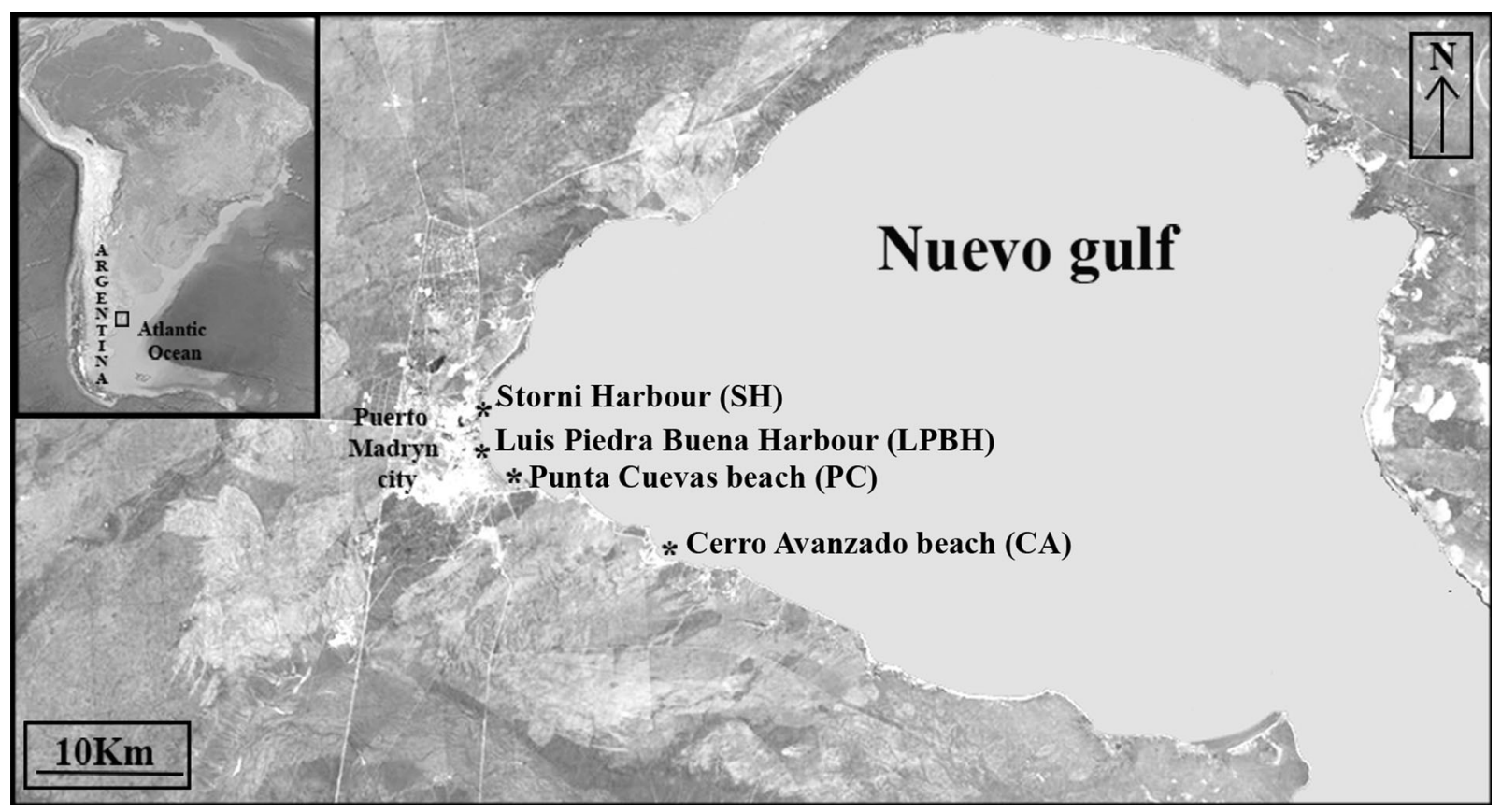

Figure 1. Sampling sites in Nuevo Gulf. 
of Trophon geversianus and Buccinanops globulosus (LPBH, PC and CA sites) as well as five specimens of Adelomelon ancilla (SH site) were collected by scuba diving in July 2011. The low number of $A$. ancilla individuals collected was due to their scarcity and slow growth. They were still included because this species is normally consumed locally. Sediment samples (up to $10 \mathrm{~cm}$ depth) were collected using plastic cores, at the sites inhabited by $A$. ancilla and B. globulosus, which live buried in this substrate most of the time. Small-sized mussels, B. rodriguezii and Perumytilus purpuratus, were collected from rocky shores where T. geversianus lives and feeds on these tiny mussels ( $\mathrm{LPBH}, \mathrm{PC}$ and $\mathrm{CA}, \mathrm{N}=20$ at each site).

\section{Sample processing}

Bulk sediments were dried at $60^{\circ} \mathrm{C}$. Granulometry was performed by passing the sample through $2 \mathrm{~mm}$ and $63 \mu \mathrm{m}$ meshes. For further analysis, particles larger than $2 \mathrm{~mm}$ were discarded. Organic matter was determined by loss on ignition at $450^{\circ} \mathrm{C}$ for $4 \mathrm{~h}$. For analysis of metals, $1 \mathrm{~g}$ of dry sediment was treated with Aqua Regia according to Agemian \& Chau (1976). This extraction method has been considered useful for evaluating the potential of aquatic sediments for biological effects (CCME 2001). Gastropods were measured $(0.1 \mathrm{~mm}$ precision digital caliper) and weighed $(0.001 \mathrm{~g}$ digital scale) and the digestive gland-gonad complex and foot were carefully separated for subsequent analysis. In the case of the bivalves that constitute the diet of Trophon geversianus, analyses were performed on total soft tissues.

Each tissue type (foot and gland-gonad complex of gastropods, and whole soft tissue of bivalves) was grouped by site and then oven dried at $60^{\circ} \mathrm{C}$. Percentage moisture was calculated as the loss of weight after drying. Dried material was homogenized in an agate mortar; $1 \mathrm{~g}$ of homogenate was placed in a crucible and calcinated in a muffle furnace (Fisher 186). Temperature was slowly increased from room temperature to $400^{\circ} \mathrm{C}$ for $6 \mathrm{~h}$. The next day, $2 \mathrm{ml}$ of concentrated $\mathrm{HNO}_{3}$ was added and evaporated to dryness on a sand bath (Thermoline Type 2200 ) at $80^{\circ} \mathrm{C}$. This procedure was repeated until white ashes were obtained. Ashes were resuspended with $4 \mathrm{ml}$ of acid solution $\left(\mathrm{HNO}_{3} 3 \% \mathrm{v} / \mathrm{v}\right.$ and $\left.\mathrm{HCl} 6 \% \mathrm{v} / \mathrm{v}\right)$ and made up to $10 \mathrm{ml}$.

All analyses were performed in triplicate and each set was accompanied by two blanks consisting of the reagents treated in the same way as the samples. The extracts were stored at $4^{\circ} \mathrm{C}$, until metal determination in an IL-457 atomic absorption spectrophotometer
(AAS). An air-acetylene flame was used, except for Al which was measured using a nitrous oxide-acetylene flame. Unless otherwise indicated, results are reported as $\mu \mathrm{g} \mathrm{g}^{-1}$ of dry wet (for sediments) and wet weight (for biota).

The total metal content (TMC) in both gastropod tissues was estimated as the weighted average of the individual contents (Foot + Digestive Gland-Gonad complex), as follows:

$$
\begin{aligned}
\operatorname{TMC}\left(\mu g \cdot g^{-1}\right)= & {[M]_{(F)} \times \frac{F \text { weight }}{F+D G-G \text { weight }} } \\
& +[M]_{(D G-G)} \times \frac{D G-G \text { weight }}{F+D G-\text { G weight }}
\end{aligned}
$$

where $[\mathrm{M}]_{(\mathrm{F})}$ and $[\mathrm{M}]_{(\mathrm{DG}-\mathrm{G})}$ are the mean metal concentrations in the foot and in the complex Digestive GlandGonads, respectively. Results were reported as $\mu \mathrm{g} \mathrm{g}^{-1}$ of wet weight.

Reagents of analytical grade (Merck) were used for the blanks and for the calibration curves. Quality assurance of sediment and organism results was done through analysis of the standard reference marine sediment PACS-2 and Oyster Tissue 1566b, respectively. For sediment samples, detection limits were $0.25(\mathrm{Cd}), 5$ (Pb), $1.25(\mathrm{Cu}), 0.25(\mathrm{Zn}), 2.5$ (Fe \%) and $10(\mathrm{Al} \%) \mu \mathrm{g}$ $\mathrm{g}^{-1}$. Recovery percentage in reference material 'Marine Sediment PACS-2' was between 81 and 102\%, and the variation coefficient was between 1.3 and $16.3 \%$. For tissue samples, detection limits were 0.03 (Cd), $0.5(\mathrm{~Pb}), 0.3(\mathrm{Cu}), 0.45(\mathrm{Zn}), 1.0(\mathrm{Fe})$ and $6.0(\mathrm{Al})$

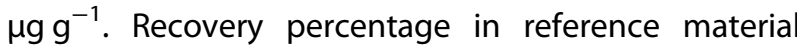
'Oyster Tissue 1566b' was between 76 and 105\%, and the variation coefficient was between 1.2 and $9.7 \%$.

\section{Health risk assessment}

Depending on the size and species, gastropods can be consumed whole or only the muscular foot. In this study, we assessed the potential human health risk of the studied metals due to consumption of all the gastropod tissues as well as only the foot. For this purpose, we compared Total Metal Content (TMC) of $\mathrm{Cd}$ and $\mathrm{Pb}$ with maximum levels $(\mathrm{ML})$ recommended by national and international regulations (SENASA 2000; MERCOSUR/GMC 2011; WHO 2006). No limits have been suggested in these regulations for the other metals. We also estimated the required intake of gastropods to reach the provisional tolerable intake of most recently (2011-2013) evaluated metals by the JECFA: Cd (PTMI: $25 \mu \mathrm{g} / \mathrm{kg}$ bw/month) and Al (PTWl: $2 \mathrm{mg} / \mathrm{kg}$ bw/week). Lead was not included, since previously established PTWI was withdrawn by 
the Committee in 2011. The Target Hazard Quotient (THQ) provides an indication of the risk level due to exposure to contaminants (USEPA 1989). In order to assess the non-carcinogenic health risk from consuming gastropods for the local population, target hazard quotients (THQ) were calculated as follows:

$$
\mathrm{THQ}=\frac{\mathrm{EF} * \mathrm{ED} * \mathrm{C} * \mathrm{FIR}}{\mathrm{RFD} * \mathrm{WAB} * \mathrm{TA}} * 0.001
$$

where $E F$ is the frequency of exposure (days/year), ED is the exposure duration (years), FIR is the rate of food intake ( $\mathrm{g} /$ person/day), $\mathrm{C}$ is the metal concentration in seafood $\left(\mu \mathrm{g} \mathrm{g}^{-1}\right)$, RFD is the oral reference dose provided by the EPA's Integrated Risk Information System (IRIS) online database (https://cfpub.epa.gov/ncea/iris/ iris_documents/documents/subst/0141_summary.pdf), WAB is the body weight $(\mathrm{kg})$ and TA is the average time of exposure to non-carcinogenic compounds (365 days/ year $\times E D)$. Estimations were only performed for $\mathrm{Cd}$ $\left(\mathrm{RFD}=1.0 \times 10^{-3} \mathrm{mg} \mathrm{kg}^{-1} /\right.$ day), since RFD for $\mathrm{Al}$ and $\mathrm{Pb}$ are not considered in the IRIS. For Argentinean consumers the EF was fixed at 48 days/year; ED 70 years; FIR $2.32 \mathrm{~g} /$ person/day; and WAB $72 \mathrm{~kg}$ (Walpole et al. 2012).

For the purposes of this paper, in accordance with the EPA guidelines, it was assumed that cooking has no effect on the toxicity of elements and the ingested dose is equal to the absorbed contaminant dose.

\section{Results and discussion}

\section{Metals in sediments}

Sediments showed oxidizing or partially oxidizing characteristics, with fine-sandy particles. The highest organic matter content was found at PC (Table I), a site that is characterized by high macroalgal biomass, resulting from drift and accumulation during north winds (Gil et al. 2014). The highest metal concentrations were measured in LPBH (Table I), in accordance with the highest amount of sediment particles below $63 \mu \mathrm{m}$ and the influence of the harbour activity. The general pattern of metal concentration in sediment samples was $\mathrm{Fe}>\mathrm{Al}>\mathrm{Zn}>\mathrm{Cu}>\mathrm{Pb}>\mathrm{Cd}$. Concentrations of $\mathrm{Fe}$ and $\mathrm{Al}$ found in this study were higher than those previously reported by Giarratano et al. (2013) in Nuevo Gulf, probably due to the different granulometry of the analysed samples. Fe and Al are geochemically abundant elements in the earth's crust and their oxyhydroxide phases may be carriers of other metals in the marine environment (Wen et al. 2008). The maximum values measured for $\mathrm{Zn}, \mathrm{Cu}$ and $\mathrm{Pb}$ were similar to those found by other authors in other Patagonian gulfs (Harvey \& Gil 1988; Giarratano et al. 2013; Marinho et al. 2013). The levels in sediments were below international guidelines for biota protection (USEPA 1977; CCME 2001). Cd was undetectable in all sediment samples, as previously reported in most coastal systems from Patagonia (Argentina).

\section{Metals in the diet of Trophon geversianus (Brachidontes rodriguezii-Perumytilus purpuratus)}

All the metals were detected in the tiny mussels Brachidontes rodriguezii-Perumytilus purpuratus, with the exception of $\mathrm{Pb}$ (Table II). Concentrations followed the pattern: $\mathrm{Fe} \sim \mathrm{Al}>\mathrm{Zn}>\mathrm{Cu}>\mathrm{Cd}>\mathrm{Pb}$ and, despite the proximity of the aluminium factory, they were in most cases below the values previously reported for the bivalve Aulacomya atra (Molina, 1782) living in the same areas (Gil et al. 1988; Giarratano et al. 2013). This result could be related to the exclusion of gills in the analysed tissues (Bebianno \& Serafim 1998).

\section{Metals in gastropods}

Metal concentrations were detected in foot and digestive gland-gonad complex of the three gastropod species (Figure 2). Cd was found in the gastropods Adelomelon ancilla and $B$. globulosus, which live most of the time buried in fine sediments, despite not being detected in the corresponding sediment matrix. Unlike other transition metals, sediment diagenesis is an important factor controlling $\mathrm{Cd}$ bioavailability. This metal migrates into pore water in the top oxidized sediment layer while the inverse occurs in the reduced deeper layers (Rosenthal et al. 1995), which is the most likely explanation of why this metal is not

Table I. Metal levels (mean \pm SD) $\left(\mu \mathrm{g} \mathrm{g}^{-1} \mathrm{dw}\right.$ ), grain size (\%) and organic matter (OM) (\%) in marine sediments from sampling sites.

\begin{tabular}{|c|c|c|c|c|c|c|c|c|c|c|}
\hline \multirow[b]{2}{*}{ Site } & \multirow[b]{2}{*}{ Al } & \multirow[b]{2}{*}{$\mathrm{Fe}$} & \multirow[b]{2}{*}{$\mathrm{Zn}$} & \multirow[b]{2}{*}{$\mathrm{Cu}$} & \multirow[b]{2}{*}{$\mathrm{Cd}$} & \multirow[b]{2}{*}{$\mathrm{Pb}$} & \multicolumn{3}{|c|}{ Grain size } & \multirow[b]{2}{*}{$\mathrm{OM}$} \\
\hline & & & & & & & $C$ & $M$ & $\mathrm{~F}$ & \\
\hline SH & $5633 \pm 866.4$ & $12,179 \pm 478.7$ & $19.36 \pm 0.88$ & $2.50 \pm 0.0003$ & ND & $5.00 \pm 0.007$ & 20.76 & 43.56 & 35.67 & 2.5 \\
\hline LPBH & $12,958 \pm 44.6$ & $13,581 \pm 290.7$ & $32.99 \pm 3.3$ & $6.10 \pm 0.2$ & ND & $7.47 \pm 0.005$ & 0.01 & 19.82 & 80.16 & 1.74 \\
\hline PC & $8664 \pm 184.6$ & $12,175 \pm 1068.3$ & $18.92 \pm 0.7$ & $2.74 \pm 0.3$ & ND & ND & 0.12 & 70.21 & 29.65 & 10.48 \\
\hline CA & $10,541 \pm 507.9$ & $10,492 \pm 84.5$ & $16.84 \pm 0.9$ & $2.99 \pm 0.001$ & ND & ND & 0.02 & 70.58 & 29.39 & 1.09 \\
\hline
\end{tabular}

Note: Abbreviations: C: coarse ( $>2 \mathrm{~mm})$, F: fine $(<63 \mu)$, M: medium $(63 \mu<$ grain $<2 \mathrm{~mm})$, ND: non-detectable concentration; CA: Cerro Avanzado beach, LPBH: Luis Piedra Buena harbour, PC: Punta Cuevas beach, SH: Storni harbour. 
Table II. Metal levels ( $\mu \mathrm{g} \mathrm{g}^{-1} \mathrm{dw}$ ) in gastropods and bivalves from the studied sites.

\begin{tabular}{|c|c|c|c|c|c|c|c|c|c|c|c|c|c|}
\hline \multirow{2}{*}{$\begin{array}{l}\text { Species } \\
\text { Bivalves: }\end{array}$} & \multirow[t]{2}{*}{ Site } & \multicolumn{2}{|c|}{$\mathrm{Al}$} & \multicolumn{2}{|c|}{$\mathrm{Fe}$} & \multicolumn{2}{|c|}{$\mathrm{Zn}$} & \multicolumn{2}{|c|}{$\mathrm{Cu}$} & \multicolumn{2}{|c|}{$\mathrm{Cd}$} & \multicolumn{2}{|c|}{$\mathrm{Pb}$} \\
\hline & & \multirow{4}{*}{\multicolumn{2}{|c|}{$\begin{array}{l}130.15 \\
282.83 \\
300.37\end{array}$}} & & & & & \multirow{2}{*}{\multicolumn{2}{|c|}{113}} & \multirow{2}{*}{\multicolumn{2}{|c|}{ ND }} \\
\hline \multirow{4}{*}{$\begin{array}{l}\text { Brachidontes rodriguezii- } \\
\text { Perumytilus purpuratus }\end{array}$} & \multirow{3}{*}{$\begin{array}{l}\text { LPBH } \\
\text { PC }\end{array}$} & & & \multirow{3}{*}{\multicolumn{2}{|c|}{$\begin{array}{c}193.53 \\
396.12 \\
94.61\end{array}$}} & \multicolumn{2}{|c|}{74.66} & \multicolumn{2}{|c|}{9.19} & & & & \\
\hline & & & & & & \multirow{2}{*}{\multicolumn{2}{|c|}{$\begin{array}{l}43.79 \\
19.75\end{array}$}} & & & \multicolumn{2}{|c|}{183} & \multicolumn{2}{|c|}{ ND } \\
\hline & & & & & & & & \multicolumn{2}{|c|}{2.26} & \multicolumn{2}{|c|}{0.52} & \multicolumn{2}{|c|}{ ND } \\
\hline & & $\mathrm{F}$ & DG-G & $\mathrm{F}$ & DG-G & $\mathrm{F}$ & DG-G & $\mathrm{F}$ & DG-G & $\mathrm{F}$ & DG-G & $\mathrm{F}$ & DG-G \\
\hline \multicolumn{14}{|l|}{ Gastropods: } \\
\hline \multirow[t]{2}{*}{ Adelomelon ancilla } & SH & ND & ND & 13.93 & 723.63 & 27.01 & 781.65 & 9.81 & 586.31 & 0.06 & 8.02 & ND & 1.81 \\
\hline & LPBH & 23.2 & 13.04 & 290.0 & 526.71 & 70.29 & 1091.15 & 24.95 & 59.73 & 0.36 & 53.12 & 1.63 & 2.61 \\
\hline \multirow[t]{3}{*}{ Buccinanops globulosus } & PC & 103.32 & 13.31 & 244.98 & 476.82 & 59.11 & 959.42 & 16.49 & 45.21 & 0.20 & 38.88 & 1.02 & 1.95 \\
\hline & CA & 22.69 & 17.21 & 82.85 & 621.69 & 77.29 & 787.09 & 17.26 & 55.81 & 0.29 & 190.24 & 1.02 & 1.98 \\
\hline & LPBH & 21.39 & ND & 184.31 & 351.57 & 199.43 & 583.56 & 21.49 & 68.93 & 0.76 & 58.82 & 1.17 & 10.37 \\
\hline \multirow[t]{2}{*}{ Trophon geversianus } & PC & 71.89 & ND & 181.97 & 400.80 & 183.09 & 504.52 & 29.77 & 75.41 & 1.23 & 104.24 & ND & 3.51 \\
\hline & CA & 54.01 & 15.55 & 131.69 & 298.01 & 136.00 & 296.06 & 19.48 & 37.38 & 0.79 & 64.78 & ND & 1.94 \\
\hline
\end{tabular}

Abbreviations: F: foot, DG-G: Digestive Gland-Gonad complex, ND: non-detectable concentrations; CA: Cerro Avanzado beach, LPBH: Luis Piedra Buena harbour, PC: Punta Cuevas beach, SH: Storni harbour.

always well correlated in sediments and organisms (Apeti et al. 2009). Therefore, the most probable sources of $\mathrm{Cd}$ in $A$. ancilla and B. globulosus would be the surrounding pore water and food; further studies should include the analysis of $\mathrm{Cd}$ in these two substrates, the surrounding pore water and food of the gastropods, in order to advance our understanding of the uptake routes.

The digestive gland-gonad complex was the main storage tissue for all measured metals, except for Al in B. globulosus and T. geversianus (Table II). The digestive gland-gonad complex was proposed in previous works as a target for metal detoxification in many invertebrate species (Rainbow 2007), while metallothionein induction is reported as an effective detoxification mechanism in other marine invertebrates (Cheung et al. 2002; Khati et al. 2012).

The levels of TMC found in this study were in general higher than concentrations found in bivalves (except for $\mathrm{Fe}$ and $\mathrm{Al}$ ) from the same region (Giarratano et al. 2013). In comparison to other species of gastropods, TCM levels in the harbour area were similar or slightly higher than those found in Nacella magellanica from the Beagle Chanel, Argentina and lower (except for Cd) than those found in different species of gastropods around the world such as Patella caerulea Linnaeus, 1758, Littorina littorea (Linnaeus, 1758), Buccinum undatum Linnaeus, 1758, Haliotis tuberculata Linnaeus,

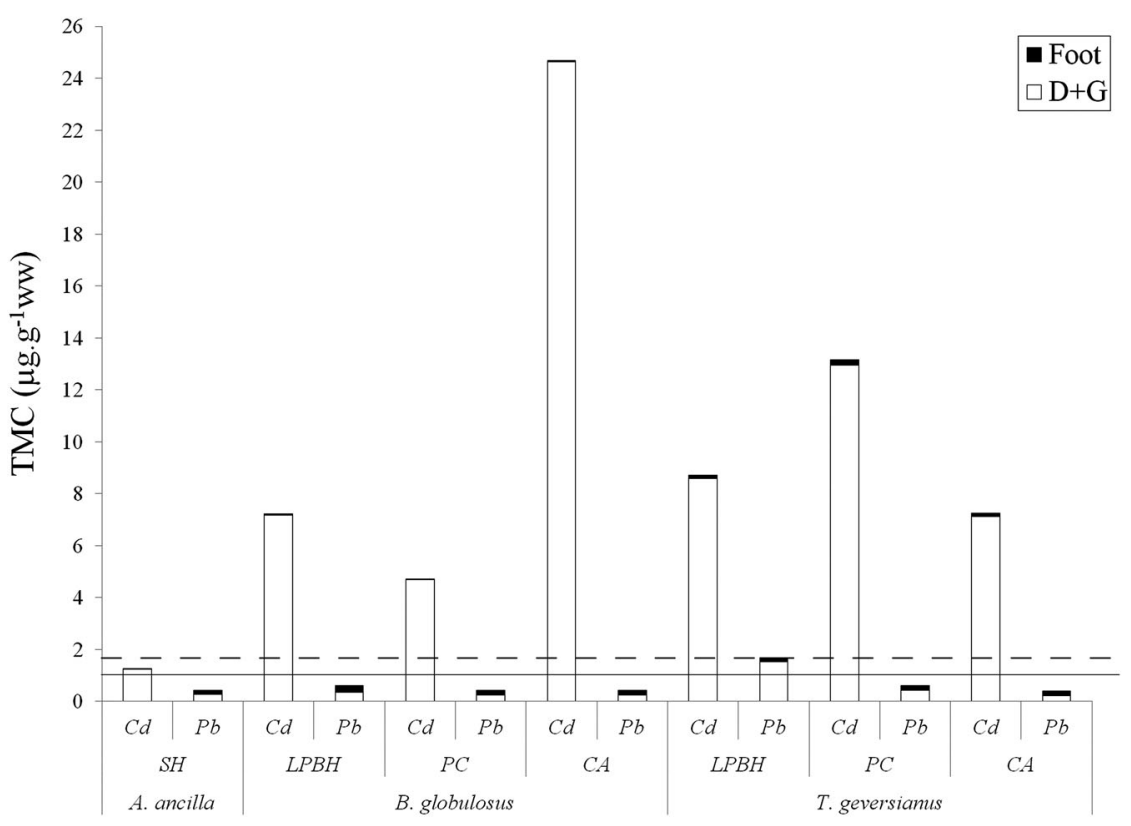

Figure 2. Total metal content ( $\mu \mathrm{g} \cdot \mathrm{g}^{-1} \mathrm{ww}$ ) in gastropods (foot and digestive gland + gonad complex). Recommended values for Cd (continuous line) and $\mathrm{Pb}$ (dashed line) in samples of mollusc for human consumption (SENASA 2000; MERCOSUR/GMC 2011; WHO 2006) are indicated. Abbreviations: CA: Cerro Avanzado beach, LPBH: Luis Piedra Buena harbour, PC: Punta Cuevas beach, SH: Storni harbour. 
1758 and Bolinus brandaris (Linnaeus, 1758), among others (Yüzereroğlu et al. 2010; Noël et al. 2011; Bille et al. 2015; Lahbib et al. 2016).

\section{Health risk assessment}

Taking into account the recommendations of SENASA (2000), MERCOSUR/GMC (2011) and WHO (2006) for samples of molluscs destined for human consumption, all samples exceeded the recommended maximum levels of $\mathrm{Cd}$ (Figure 2), and only T. geversianus in $\mathrm{LPBH}$ exceeded the levels of $\mathrm{Pb}$.

Regarding the provisional tolerable intake, a monthly ingestion of $1.2 \mathrm{~kg}$ of Adelomelon ancilla, $0.065 \mathrm{~kg}$ of B. globulosus or $0.12 \mathrm{~kg}$ of Trophon geversianus entire gastropod tissues would be enough to reach the PTMI for Cd (25 $\mu \mathrm{g} / \mathrm{kg}$ bw/month). However, if only the foot tissues were consumed, ingested amounts to reach that limit would increase towards 83, 15 and $4.4 \mathrm{~kg}$ for A. ancilla, B. globulosus and T. geversianus respectively. In the case of $\mathrm{Al}$, and considering that the foot presented the highest concentrations, $7 \mathrm{~kg}$ of this tissue of B. globulosus or $10.3 \mathrm{~kg}$ from $T$. geversianus could be consumed in a week to reach the established PTWI ( $2 \mathrm{mg} / \mathrm{kg}$ bw/week).

According to these estimations, $B$. globulosus would be the less safe species to consume, mainly due to $\mathrm{Cd}$ levels. However, the highest THQ obtained for this metal was 0.1, much lower than 1, which would mean that the daily exposure at the measured level would be unlikely to cause any health risks. However, if exported to countries where the consumption of marine gastropods is higher, the THQ values should be re-calculated, as these increase with the food intake ratio.

On the other hand, $A$. ancilla seems to be the safest species for human consumption. However, Zabala et al. (2013b) have recommended not to use it as a fishing resource in Nuevo Gulf, because of its slow growth, low densities and low fertility, and this must be taken into account.

\section{Conclusions}

This study suggests that according to local consumption habits, dietary intake of the studied gastropods is probably safe. However, it must be kept in mind that $\mathrm{Cd}$ and $\mathrm{Pb}$ concentrations exceeded maximum levels (mainly in the harbour area) and that risk may increase if the food intake ratio is enhanced. In order to protect public health, monitoring of toxic metals and other pollutants in fishing resources for human consumption should be sustained over time by local authorities.

\section{Acknowledgements}

Special thanks to Carmen Marinho from Centro para el Estudio de los Sistemas Marinos (CESIMAR) for her assistance with sample processing. Ricardo Vera, Fabián Quiroga, Néstor Ortiz and Julio Rúa helped with sampling. This is publication No. 82 of the Laboratorio de Reproducción y Biología Integrativa de Invertebrados Marinos (LARBIM).

\section{Disclosure statement}

No potential conflict of interest was reported by the authors.

\section{Funding}

This research was partially supported by the projects PICT 1232, PICT 2929, PICT 2709, PICT 1491, PICT 1476, PIP 067 and the PADI foundation.

\section{References}

Agemian H, Chau ASY. 1976. Evaluation of extraction techniques for the determination of metals in aquatic sediments. The Analyst 101:761-67. doi:10.1039/ an9760100761

Apeti DA, Lauenstein GG, Riedel GF. 2009. Cadmium distribution in coastal sediments and mollusks of the US. Marine Pollution Bulletin 58:1016-24. doi:10.1016/j. marpolbul.2009.02.013

APPM. 2016. Administración Portuaria de Puerto Madryn. http://www.appm.com.ar/estadisticas (accessed 21 January 2017).

Bat L, Arici E, Sezgin M, Şahin F. 2016. Heavy metals in edible tissues of benthic organisms from Samsun coasts, South Black Sea, Turkey and their potential risk to human health. Journal of Food and Health Science 2:57-66. doi:10.3153/JFHS16006

Bebianno MJ, Serafim MA. 1998. Comparison of metallothionein induction in response to cadmium in the gills of the bivalve molluscs Mytilus galloprovincialis and Ruditapes decussatus. Science of the Total Environment 214:123-31. doi:10.1016/S0048-9697(98)00059-X

Bigatti G, Ciocco NF. 2008. Volutid snails as an alternative resource for artisanal fisheries in Northern Patagonic gulfs: availability and first suggestions for diving catches. Journal of Shellfish Research 27:417-21. doi:10.2983/ 0730-8000(2008)27[417:VSAAAR]2.0.CO;2

Bigatti G, Primost MA, Cledón $M$, Averbuj A, Theobald $N$, Gerwinski W, et al. 2009. Biomonitoring of TBT contamination and imposex incidence along $4700 \mathrm{~km}$ of Argentinean shoreline (SW Atlantic: from $38 \mathrm{~S}$ to $54 \mathrm{~S}$ ). Marine Pollution Bulletin 58:695-701. doi:10.1016/j. marpolbul.2009.01.001

Bigatti G, Cumplido M, Averbuj A. 2015. Gasterópodos de interés comercial en la Provincia del Chubut. Informe para la Mesa Técnica Zona 1. LAPEMAR, Laboratorio de Peces y Mariscos de Interés Comercial (CENPAT). Subsecretaría de 
Pesca de Chubut - Reglamentación de la pesca de gasterópodos. Technical Report no. 31.

Bille L, Binato G, Cappa V, Toson M, Dalla Pozza M, Arcangeli $\mathrm{G}$, et al. 2015. Lead, mercury and cadmium levels in edible marine molluscs and echinoderms from the Veneto Region (north-western Adriatic Sea - Italy). Food Control 50:36270. doi:10.1016/j.foodcont.2014.09.018

Blackmore G, Morton B. 2002. The influence of diet on comparative trace metal cadmium, copper and zinc accumulation in Thais clavigera (Gastropoda: Muricidae) preying on intertidal barnacles or mussels. Marine Pollution Bulletin 44:870-76. doi:10.1016/S0025-326X(02)00089-9

Bökenhans V. 2014. Estimación de la Edad y Crecimiento de dos Poblaciones de Buccinanops globulosus del Golfo Nuevo. Puerto Madryn, Argentina: Facultad de Ciencias Naturales. 53 pages.

Bryan GW, Gibbs PE, Hummerstone LG, Burt GR. 1987. Copper, zinc, and organotin as long-term factors governing the distribution of organisms in the fal estuary in Southwest England. Estuaries 10:208-19. doi:10.2307/1351849

Butler A. 1998. Acquisition and utilization of transition metal ions by marine organisms. Science 281:207-09. doi:10. 1126/science.281.5374.207

CCME. 2001. Canadian sediment quality guidelines for the protection of aquatic life: summary tables, updated. In: Canadian Environment Quality Guidelines, 1999. Winnipeg, MB: Canadian Council of Ministers of the Environment. p 1-7.

Cheung SG, Tai KK, Leung CK, Siu YM. 2002. Effects of heavy metals on the survival and feeding behaviour of the sandy shore scavenging gastropod Nassarius festivus (Powys). Marine Pollution Bulletin 45:107-13. doi:10.1016/ S0025-326X(01)00324-1

Conti ME, Stripeikis J, Finoia MG, Tudino MB. 2011. Baseline trace metals in bivalve molluscs from the Beagle Channel, Patagonia (Argentina). Ecotoxicology 20:134153. doi:10.1007/s10646-011-0690-5

Conti ME, Stripeikis J, Botrè F, Tudino MB. 2012a. Trace metals intake of Nacella (P) magellanica from the Beagle Channel, Tierra del Fuego (Patagonia, Argentina). International Journal of Environment and Health 6:84-91. doi:10.1504/ IJENVH.2012.046857

Conti ME, Stripeikis J, Finoia MG, Tudino MB. 2012b. Baseline trace metals in gastropod mollusks from the Beagle Channel, Tierra del Fuego (Patagonia, Argentina). Ecotoxicology 21:1112-25. doi:10.1007/s10646-012-0866-7

Copat C, Conti GO, Signorelli C, Marmiroli S, Sciacca S, Vinceti M, Ferrante M. 2013. Risk assessment for metals and PAHs by Mediterranean seafood. Food and Nutrition Sciences 4: 10-13. doi:10.4236/fns.2013.47A002

Del Brio F, Commendatore MG, Castro IB, Gomes Costa P, Fillmann G, Bigatti G. 2016. Distribution and bioaccumulation of butyltins in the edible gastropod Odontocymbiola magellanica. Marine Biology Research 12:608-20. DOI: 10. 1080/17451000.2016.1169296

Di Salvatore P, Calcagno JA, Ortíz N, Ríos de Molina MC, Sabatini SE. 2013. Effect of seasonality on oxidative stress responses and metal accumulation in soft tissues of Aulacomya atra, a mussel from the South Atlantic Patagonian coast. Marine Environmental Research 92:244-52. doi:10.1016/j.marenvres.2013.10.004
Exley C, Mold MJ. 2015. The binding, transport and fate of aluminium in biological cells. Journal of Trace Elements in Medicine and Biology 30:90-95. doi:10.1016/j.jtemb.2014. 11.002

Giarratano E, Gil MN, Malanga G. 2013. Assessment of antioxidant responses and trace metal accumulation by digestive gland of ribbed mussel Aulacomya atra atra from Northern Patagonia. Ecotoxicology and Environmental Safety 92:3950. doi:10.1016/j.ecoenv.2013.02.007

Gil MN, Harvey M, Esteves JL. 1988. Metal content in bivalve molluscs from the San José and Nuevo Gulfs, Patagonia Argentina. Marine Pollution Bulletin 19:181-82. doi:10. 1016/0025-326X(88)90676-5

Gil MN, Harvey MA, Esteves JL. 1999. Heavy metals in intertidal surface sediments from the Patagonian Coast, Argentina. Bulletin of Environmental Contamination and Toxicology 63:52-58. doi:10.1007/s001289900947

Gil MN, Torres A, Harvey M, Esteves JL. 2006. Metales pesados en organismos marinos de la zona costera de la Patagonia argentina continental. Revista de Biologia Marina y Oceanografia 41:167-76.

Gil MN, Torres A, Marinho C, Esteves JL. 2014. Caracterización de sedimentos costeros y flujos bentónicos en una bahía patagónica de Argentina: antes y después de la eliminación del efluente urbano. In: Marcovecchio J, Botte S, Freije $\mathrm{RH}$, editors. Procesos Geoquimicos Superficiales en Iberoamerica Salamanca, España, Sociedad Iberoamericana de Fisica y Quimica Ambiental. Bahia Blanca, Argentina: SIFyQA, p 37-52.

Gust M, Buronfosse T, Geffard O, Coquery M, Mons R, Abbaci $\mathrm{K}$, et al. 2011. Comprehensive biological effects of a complex field poly-metallic pollution gradient on the New Zealand mudsnail Potamopyrgus antipodarum (Gray). Aquatic Toxicology 101:100-08. doi:10.1016/j. aquatox.2010.09.007

Harvey MA, Gil MN. 1988. Concentrations of some trace elements in recent sediments from the San José and Nuevo Gulfs, Patagonia Argentina. Marine Pollution Bulletin 19:394-96. doi:10.1016/0025-326X(88)90276-7

Khati W, Ouali K, Mouneyrac C, Banaoui A. 2012. Metallothioneins in aquatic invertebrates: their role in metal detoxification and their use in biomonitoring. Energy Procedia 18:784-94. doi:10.1016/j.egypro.2012.05. 094

Lahbib Y, Mleiki A, Menif NT-E. 2016. Bioaccumulation of trace metals in Hexaplex trunculus: spatial and temporal trends from 2004 to 2011 along the Tunisian coast. Environmental Science and Pollution Research 23:1625971. doi:10.1007/s11356-016-6723-0

Langston WJ, Bebianno MJ, Burt GR. 1998. Metal handling strategies in molluscs. In: Langston WJ, Bebianno MJ, editors. Metal Metabolism in Aquatic Environments. London, Springer, p 219-83.

Marigómez I, Soto M, Cajaraville MP, Angulo E, Giamberini L. 2002. Cellular and subcellular distribution of metals in molluscs. Microscopy Research and Technique 56:358-92. doi:10.1002/jemt.10040

Marinho CH, Gil MN, Esteves JL. 2013. Distribution and origin of trace metals in sediments of a marine park (Northern San Jorge Gulf) from Argentina. Marine Pollution Bulletin 72:260-63. doi:10.1016/j.marpolbul.2013.04.019 
Massara Paletto V, Commendatore MG, Esteves JL. 2008. Hydrocarbon levels in sediments and bivalve mollusks from Bahía Nueva (Patagonia, Argentina): an assessment of probable origin and bioaccumulation factors. Marine Pollution Bulletin 56:2100-105. doi:10.1016/j.marpolbul. 2008.08.026

Meador JP, Stein JE, Reichert WL, Varanasi U. 1995. Bioaccumulation of polycyclic aromatic hydrocarbons by marine organisms. In: Ware GW, editor. Reviews of Environmental Contamination and Toxicology. New York: Springer, p 79-165.

MERCOSUR/GMC. 2011. Reglamento técnico MERCOSUR sobre límites máximos de contaminantes inorgánicos en alimentos. RES. No 12/11, Grupo Mercado Comun. Secretaría de Políticas, Regulación e Institutos y Secretaría de Agricultura, Ganadería y Pesca. Código Alimentario Argentino. http://www.infoleg.gov.ar/infoleg Internet/anexos/195000-199999/199977/norma.htm (accessed 21 January 2017).

Narvarte MA. 2006. Biology and fishery of the whelk Buccinanops globulosum (Kiener, 1834) in northern coastal waters of the San Matías Gulf (Patagonia, Argentina). Fisheries Research 77:131-37. doi:10.1016/j.fishres.2005.11. 006

Noël L, Testu C, Chafey C, Velge P, Guérin T. 2011. contamination levels for lead, cadmium and mercury in marine gastropods, echinoderms and tunicates. Food Control 22:433-37. doi:10.1016/j.foodcont.2010.09.021

Rainbow PS. 2007. Trace metal bioaccumulation: models, metabolic availability and toxicity. Environment International 33:576-82. doi:10.1016/j.envint.2006.05.007

Regoli F, Orlando E. 1994. Seasonal variation of trace metal concentrations in the digestive gland of the Mediterranean mussel Mytilus galloprovincialis: comparison between a polluted and a non-polluted site. Archives of Environmental Contamination and Toxicology 27:36-43. doi:10.1007/BF00203885

Rosenthal Y, Boyle E, Labeyrie L, Oppo D. 1995. Glacial enrichments of authigenic $\mathrm{Cd}$ and $\mathrm{U}$ in subantarctic sediments: a climatic control on the elements' oceanic budget? Paleoceanography 10:395-413. doi:10.1029/ 95PA00310

Scarabino F, Zaffaroni JC, Carranza A, Nin M. 2006. Gasterópodos marinos y estuarinos de la costa uruguaya: faunística, distribución, taxonomía y conservación. In: Menafra R, Rodriguez-Gallego L, Scarabino F, Conde $D$, editors. Bases para la Conservación y el Manejo de la Costa Uruguaya. Montevideo: Vida Silvestre, p 143-156.
Scarabino V. 1977. Moluscos del Golfo San Matías, provincia de Río Negro, República Argentina. Inventario y claves para su identificación. Comisión de la Sociedad Malacológica del Uruguay 4:177-285.

SENASA. 2000. Servicio Nacional de Sanidad y Calidad Agroalimentaria. Decreto 4238/68. Capítulo XXIII del Reglamento sanitario de explotación y comercialización de moluscos y bibalvos vivos para consumo humano directo. Inciso 23.24.2.5: Calidad Química (Res. SAGPYA N 53 del 30/09/98). http://senasa.gob.ar/sites/default/files/ARBOL_ SENASA/INFORMACION/NORMATIVA/4238/capitulo_xxiii. pdf) (accessed 21 January 2017).

USEPA. 1977. Guidelines for the Pollution Classification of Great Lakes Harbor Sediments. Chicago: U.S. Environmental Protection Agengy, Region V. 8 pages.

USEPA. 1989. Risk Assessment Guidance for Superfund, Volume I, Human Health Evaluation Manual (Part A). Washington, DC: Interim Final. 291 pages.

Walpole SC, Prieto-Merino D, Edwards P, Cleland J, Stevens G, Roberts I. 2012. The weight of nations: an estimation of adult human biomass. BMC Public Health 12:e439. 6 pages. doi:10.1186/1471-2458-12-439

Wang W, Ke C. 2002. Dominance of dietary intake of cadmium and zinc by two marine predatory gastropods. Aquatic Toxicology 56:153-65. doi:10.1016/S0166-445X(01)00205-3

Wen L-S, Warnken KW, Santschi PH. 2008. The role of organic carbon, iron, and aluminium oxyhydroxides as trace metal carriers: comparison between the Trinity River and the Trinity River Estuary (Galveston Bay, Texas). Marine Chemistry 112:20-37. doi:10.1016/j.marchem.2008.06.003

WHO. 2006. Safety evaluation of certain food additives and contaminants. Sixty-fourth report of the Joint FAO/WHO Expert Committee on Food Additives (JECFA). Geneva: WHO Report 930. 100 pages.

Yüzereroğlu TA, Gök G, Çoğun HY, Firat Ö, Aslanyavrusu S, Maruldalı O, Kargin F. 2010. Heavy metals in Patella caerulea (Mollusca, Gastropoda) in polluted and non-polluted areas from the Iskenderun Gulf (Mediterranean Turkey). Environmental Monitoring and Assessment 167:257-64. doi:10.1007/s10661-009-1047-x

Zabala S, Bigatti G, Botto F, Iribarne OO, Galván DE. $2013 a$. Trophic relationships between a Patagonian gastropod and its epibiotic anemone revealed by using stable isotopes and direct observations. Marine Biology 160:90919. doi:10.1007/s00227-012-2143-y

Zabala S, Penchaszadeh PE, Panarello HO, Brogger MI, Bigatti G. 2013b. Life history parameters in the edible snail Adelomelon ancilla from Patagonian waters. Malacologia 56:215-29. doi:10.4002/040.056.0212 